Ana Dili Eğitimi Dergisi
$\begin{gathered}\text { Journal of Mother Tongue Education } \\ \text { www.anadiliegitimi.com }\end{gathered}$
Gelis/Received: 30.03 .2017 Kabul/Accepted:07.04.2017

\title{
Okuma Stratejileri Öğretiminin Türkçeyi Yabancı Dil Olarak Öğrenen Öğrencilerde Okuduğunu Anlama Becerisine Etkisi*
}

\author{
Ahmet $B A L C I^{* *}$ \\ Semih Alper DÜNDAR ${ }^{* * *}$
}

\begin{abstract}
Öz
$\mathrm{Bu}$ araştırmanın genel amacı bilişsel okuma stratejilerinin Türkçeyi yabancı dil olarak öğrenen öğrencilerin okuduğunu anlama becerilerine etkisini belirlemektir. Bu amaç doğrultusunda yarı deneysel desen kullanılmış ve araştırmanın çalışma grubunda Türkçeyi yabancı dil olarak öğrenen 20 kişi yer almıştır. Araştırma verileri Öğrencilerin kur düzeyine uygun olarak araştırmacılar tarafından hazırlanan çoktan seçmeli okuduğunu anlama testleri ile toplanmış ve Ortak Değişkenli Varyans Analizi (ANCOVA) analiz edilmiştir. Araştırma sonuçlarına göre gruplara uygulanan sontest sonucunda kontrol grubunun puanlarının aritmetik ortalaması 30,00 iken deney grubunun puanlarının aritmetik ortalamasını 53,75 olduğu görülmektedir. Bu bulguya göre deney grubu ile kontrol grubunun son-test puanlarının aritmetik ortalamaları arasında deney grubunun lehine anlamlı bir fark olduğu söylenebilir. Ortak değişkenli varyans analiz (ANCOVA) sonuçları incelendiğinde ortalama puanlar arasında anlamlı bir fark bulunmuştur. Elde edilen bu sonuçlar, yabancı dil olarak Türkçe öğretiminde okuma stratejilerinin öğretiminin öğrenci başarısını artırdığını göstermektedir.
\end{abstract}

Anahtar Kelimeler: Türkçenin Yabancı Dil Olarak Öğretimi, Okuma Eğitimi, Bilişsel Okuma Stratejileri.

\section{The Effects of Reading Strategies Instruction on the Reading Comprehension Skill of the Students who Learn Turkish as a Foreign Language}

\begin{abstract}
The main purpose of this research is to determine effect of cognitive reading strategies on the reading comprehension skills of students who learn Turkish as a foreign language. In accordance with this purpose, a quasi-experimental research design was used, and study group consisted of 20 students who were learning Turkish as a foreign language. The data were collected through level appropriate multiple-choice reading comprehension tests which were developed by the researchers in accordance with the level of the students and were analyzed, using covariance analysis (ANCOVA). Based on the results of the post-test which was administered to the groups, it was seen that while the arithmetic mean score of the control group was 30,00 , the arithmetic mean score of the experimental group was 53,75 . Based on this finding, a significant difference
\end{abstract}

\footnotetext{
* Bu makale Semih Alper Dündar'ın Yrd. Doç. Dr. Ahmet Balcı danışmanlığında hazırladığı "Bilişsel Okuma Stratejilerinin Türkçeyi Yabancı Dil Olarak Öğrenen Öğrencilerde Okuduğunu Anlama Becerisine Etkisi” başlıklı yüksek lisans tezinden üretilmiştir.

** Yrd. Doç. Dr., Mustafa Kemal Üniversitesi, Eğitim Fakültesi, Türkçe ve Sosyal Bilimler Eğitimi Bölümü, Hatay. E-posta: abalci@mku.edu.tr / ahmetbalci01@gmail.com

*** Türkçe Öğretmeni, Millî Eğitim Bakanlığı, Ankara. E-posta: semihalperdundar@gmail.com
} 
appeared between the arithmetic means of the final test scores belonging to the experimental and control groups in favor of the former. It was found that there was also a significant difference between the averages of the groups when the results of the covariate analysis of variance (ANCOVA) were examined. The results indicated that reading strategy instruction had a positive impact on the reading achievement of students who were learning Turkish as foreign language.

Keywords: Teaching Turkish as a foreign language, Reading instruction, Cognitive reading strategies.

\section{Giriş}

Temel iletişim aracı olan dil, aynı zamanda anlama ve anlatma etkinliklerimizin bütününü kapsar. Bu etkinliklerde başarılı olmanın yolu dili etkili kullanmaktan geçmektedir. Dilin etkili kullanımı ise ancak nitelikli bir dil eğitimi ile mümkündür. Bu eğitim süreci dili öğrenmeyi ve kullanmayı etkilediği kadar düşünme, analiz ve sentez becerileri gibi pek çok zihinsel süreci de etkiler. Günümüzde dil öğretiminin sınırları bu geniş bakış açısıyla çizilmekte, eğitim basamakları ve süreci bu bakış açısıyla zenginleştirilmektedir. Iletişim olanaklarının ilerlemesine bağlı olarak toplumlararası etkileşimin artması, dillerin ana dili olarak öğretimi kadar yabancı dil olarak öğretim sürecini de hızlandırmıştır. Bu süreçten Türkçe de etkilenmiş, "yabancılara Türkçe öğretimi” gelişen bir alan olarak gündemdeki yerini almıştır.

Okuma; dil becerileri içerisinde bireye öğrenme alanlarının kapısını açması yönüyle en önemli beceri alanlarından biridir. "1. Yazıya geçirilmiş bir metne bakarak bunu sessizce çözümleyip anlamak veya aynı zamanda seslere çevirmek. 2. Yazılmış bir metnin iletilmek istediği şeyleri öğrenmek." olarak tanımlanan (TDK, 2005: 1494) okuma "görme, algılama, seslendirme, anlama, beyinde yapılandırma" gibi farklı basamaklar içerir (Güneş, 2013: 128). Okuma sürecinin başındaki sembolü görme ve tanıma, nihai hedef olan anlamlandırma için sadece ön koşul olarak karşımıza çıkar. Okuma "anlamayı" gerçekleştirmek için yapılır ve bu sürecin tamamlanması okuyucu ve yazar arasında kurulacak olan görüş alışverişiyle gerçekleştirilebilir (Akyol, 2013). Bu süreçte okuyucu metni anlama sürecinde ön bilgilerini kullanmaktadır.

Yeni bir anlam kurma süreci olarak nitelendirilebilecek olan okumada bilişsel, duyuşsal ve devinişsel becerilerin birarada kullanılması gerekir (Sever, 1997). Bilişsel ve psikomotor becerilerin uyum içinde kullanımını gerektiren okuma becerisinin eğitimi bireyde anlama becerisini geliştirme yanında okuma alışkanlığı kazandırma, akıcı okuma ve söz varlığını geliştirmeyi de hedefler (MEB, 2015). Bu niteliklerin kazanılmasında bireysel faktörler kadar aile, okul, öğretim programları gibi farklı çevresel faktörlerin de etkisi unutulmamalıdır.

Okumanın temel bilgi edinme vasıtası olarak görülmesi ve bireysel olduğu kadar toplumsal gelişmişlik düzeyi ölçütlerinden bir hâline gelmesi bu konudaki dikkati daha da arttırmıştır. Okuma eğitimi sürecinin önemli başlıklarını oluşturan metin, metin türleri, metin nitelikleri, anlama 
stratejileri gibi konular nitelikli bir okuma eğitimi sürecinin vazgeçilmez araştırma konuları arasına girmesini sağlamıştır. Metin bir cümleler bütünü olmanın ötesinde anlamsal bir birlikteliği içerir (Halliday ve Hasan, 1976). De Beaugrande ve Dressler'in (1981) bağdaşıklık, tutarlılık, amaçlıık, ikna edicilik (kabul edilebilirlik), bilgilendiricilik, duruma uygun olma ve metinlerarasılık başlıkları altında topladığı metinlerarasılık nitelikleri ise aynı zamanda bireyin anlama sürecinde dikkat etmesi gereken unsurları da gösterir. Metinlerdeki yapısal farklılıklar anlama sürecini doğrudan etkilemektedir (İşeri, 1998). Okuduğunu anlama sürecinde metni ve metne ait unsurları farkettirmenin ve öğretim sürecini düzenlemenin en önemli başıklarından birini de okuduğunu anlama stratejileri oluşturmaktadır.

Okuduğunu anlama sürecinde kullanılan okuduğunu anlama stratejileri öğrenme kuramlarındaki gelişmelerle gündeme gelmiştir. Ertürk (1972) öğrenmeyi, yaşantı ürünü ve nispeten kalıcı izli davranış değişikliği olarak tanımlar. Öğrenmenin nasıl gerçekleştiği sorusuna cevap arayan araştırmacılar birçok öğrenme kuramının temelini atmıştır. Schunk (2009), bu kuramları; Koşullanma Teorileri, Sosyal Bilişsel Teori, Bilişsel Bilgi İşlem Teorisi ve Yapılandırmacı Teori başlıkları altında değerlendirir. Öğrenme kuramları içinde özellikle bilişsel kuram okuma stratejilerinin geliştirilmesine zemin hazırlamıştır. Bilişsel psikoloji 1879 yılında Wilhelm Wundt'un öncülüğünde gelişmeye başlar ve davranış̧ı kuramın öğrenmeyle ilgili açıklamalarına zihinsel faaliyetleri merkeze alarak eleştirel bir gözle karşı çıkar. Genel anlamda uyarıcı-tepki süreçlerinin ötesinde hem davranışı meydana getiren mekanizmaları hem de algı, dil ve genel olarak bilişi açıklamaya çalışır (Smith ve Kosslyn, 2014). Bilişsel kuramda bilginin başlangıçta dikkat alanına girdikten sonra duyuşsal kayıt vasıtasıyla kısa süreli belleğe gönderildiği, bunu sırasıyla bilginin işlendikten sonra uzun süreli belleğe gönderilmesi, anlamlandırıması, ayrıntılandırılması, doğru örgütlenmesi ve ihtiyaç duyulduğunda önceki öğrenmelerle ilişki kurulurak geri çağrılmasının (Schunk, 2009) izlediği açıklanır. Bu süreçte biliş, algı, dikkat, kodlama, geri çağırma gibi kavramlar önem kazanmıştır. Genel anlamda "dilin edinildiği" anlayışı (Güneş, 2013) bilişsel kuramla yaygınlaşır.

Bilişsel kuramın okuma eğitimi sürecine en önemli etkilerinden biri okuduğunu anlama stratejileri ile ilgilidir. Strateji genel olarak “önceden belirlenen bir amaca ulaşmak için tutulan yol" (TDK, 1998: 2032) anlamına gelir. Okuduğunu anlama sürecinde bireye rehberlik eden stratejiler metnin çözümlenmesi ve anlamlandırılmasını sağlar. Strateji kullanımı metindeki içeriğin ve yapının anlaşılmasına katkı sağlar. Dikkatini metne odaylayan okur bu yolla metni hem daha kolay değerlendirir hem de metnin hatırlanma süreci kolaylaşır (Akyol, 2013).

Strateji kullanımının bilinç ile açıklanması okuma stratejilerinin biliş ve bilişüstü kavramlarıyla açıklanmasını da sağlar. Wellman (1988) bir davranış ve uygulamanın strateji olarak kabul edilmesinde "kasıtlı" kullanıma ve "farkındalık" sürecine dikkat çeker. Okuduğunu anlama sürecinde kullanılan stratejiler genel anlamda okuma öncesi, okuma esnası ve okuma sonrasında kullanılan 
Okuma Stratejileri Öğretiminin Türkçeyi Yabancı Dil Olarak Öğrenen Öğrencilerde Okuduğunu Anlama Becerisine Etkisi

stratejiler olarak sınıflanmaktadır. Farklı araştırmalarda küçük değişikliklerle değerlendirilen okuma stratejilerini Paris, Wasik ve Turner (1996) şu şeklide sınıflamıştır:

Okuma Öncesinde Kullanılan Stratejiler:

1. İyi fiziksel ortam oluşturma

2. Okuma amacını belirleme

3. Önbilgilere ulaşma

4. Başlık hakkında sorular sorma

5. Kavram haritası oluşturma

6. Ana düşünceyi tahmin etmek için metni tarama

7. Metni tarayıp başlıkları, resimleri ve alt başlıkları değerlendirme

8. Bilgileri gözden geçirme

9. Metin türünü ve tarzını (üslubunu) tespit etme

10. Konu hakkında ne bilindiğini ifade etme

11. Okunacak metinde neler olabileceğini tahmin etme

\section{Okuma Esnasında Kullanılan Stratejiler:}

1. Okuma ile birlikte anlamayı kontrol etme

2. Ana düşünceyi bulma

3. Metinden anlamlar çıkarma

4. Metin türünün kalıplarını tespit etme

5. Konuşma çizgilerine bakma

6. Yeni kelimeleri kontrol etme (not alma)

7. Her paragrafın ana fikrini tahmin etme

8. Metni yorumlama

9. Okunan metinle ön bilgileri karşılaştırma

10. Öğrenilen bilgilere değer biçme

11. Metni yeniden okuma veya metnin üzerinden geçme

\section{Okuma Sonrasında Kullanılan Stratejiler:}

1. Metin ve yazarı kişisel olarak eleştirme

2. Okuma öncesindeki beklentilere dönüp gerçekleşip gerçekleşmediğini kontrol etme

3. Notları, yorumları ve altı çizilen yerleri gözden geçirme

4. Metinden çıkarılan anlamı ifade etme

5. Bilgileri bir araya toplayıp pekiştirme

6. Bilgileri gözden geçirme 
7. Bilgileri detaylandırma ve değerlendirme

8. intiyaç duyulan ek bilgileri ifade etme

9. Yeni bilgileri zihinde tutma

10. Metinle öz yaşantıları karşılaştırma

11. Metni akademik olarak eleştirme

Strateji kullanan okuyucu metin hakkındaki ön bilgilerini harekete geçirir, tahminlerde bulunur, doğru strateji seçimini yapar ve bilgiyi sürekli kontrol eder. Bu kontrol okuyucunun ana fikri ve yan fikirleri de belirlemesini kolaylaştırır (Bauman, 1984). Böylece okuyucu metin içi ve metin dışı unsurları gittikçe otomatikleşen bir süreçle kontrol eder. Strateji kullanımı bir süre sonra iyi/tecrübeli okuyucularla zayıf/tecrübesiz okuyucular arasında belirgin farklılıkların ortaya çıkmasını sağlar (Lovett ve Flavell, 1990).

Dil becerileri içinde önemli bir yeri olan okuma becerisi bireyin hayatın her alanında yetkinlik kazanmasının da yolunu açar. Bu sebeple yabancı dil öğretimi sürecinin de önemli başlıklarından birini okuma becerisinin geliştirilmesi oluşturur. Nitekim günümüzde Avrupa Konseyinin toplam 47 üye ülkesiyle birlikte uygulanan Avrupa Dil Gelişim Dosyası (European Language Portfolio) projesi de okumayı geliştirilmesi gereken temel dil becerileri arasında sayar (Council of Europe, 2002). Böylece her bireyin "Avrupa Ortak Dil Kriterleri" doğrultusunda bir "dil pasaportuna" sahip olması hedeflenmektedir. İkinci dil öğrenen bireylerin öğrenmekte oldukları dildeki okuma becerileri ve strateji kullanımı arasında olumlu yönde bir ilişkinin olduğu sonucuna ulaşılmıştır (Hosenfeld, 1977; Knight, Padron ve Waxman, 1985; Block 1986; Sarig, 1987). Araştırma sonuçları, strateji kullanımının, başarılı okuyucu davranışları arasında olduğunu göstermektedir. Ancak Upton'un (1997) araştırmasında ikinci dil öğrenenlerin genelde daha az sayıda strateji kullandığını da göstermektedir. İkinci (yabancı) dilde okuma stratejileri konusunda üstbilişsel eğitimin rolü hakkında yapılan bazı çalışmalar da (Carell, 1985; Hamp ve Lyons, 1985; Barnett, 1988; Kern, 1989; Janzen, 2003) özellikle metin yapısı özelliklerinin tanınması ve anlaşılması üzerinde yoğunlaşmıştır. Yapılan araştırmalar geleneksel eğitim gören kontrol gruplarına kıyasla strateji eğitimi verilen deney gruplarında önemli olumlu etkilerin ortaya çıktığını göstermektedir.

Türkçenin yabancı dil olarak öğrenilmesi ve öğretilmesi son yıllarda gündemimizi daha yoğun bir şekilde ilgilendirmeye başlamıştır. Yurt dışında çalışan Türk işçileri, Türklerin yoğun yaşadığı bölgelerdeki okullarda çalışan öğretmen ve idareciler, yurt dışı üniversitelerdeki Türkoloji öğrencileri, ülkemizle ticari ilişkilerde bulunan bireyler, yurt içindeki yabancılar, Türk üniversitelerindeki yabancı öğrenciler (Koç, 1998) gibi farklı gruplar Türkçenin yabancı dil olarak öğretim sürecini hızlandırmıştır. Bu gelişmede üniversitelerdeki Türkçe öğretim merkezlerinin çalışmaları da önemli bir etkiye sahiptir. 
Okuma Stratejileri Öğretiminin Türkçeyi Yabancı Dil Olarak Öğrenen Öğrencilerde Okuduğunu Anlama Becerisine Etkisi

Bu gelişmelerin doğal bir sonucu olarak yabancılara Türkçe öğretimi konusunda akademik çalışmaların sayısında da belirgin bir artış görülmeye başlanmıştır.

Okuduğunu anlama stratejilerinin öğretimi ile ilgili olarak ülkemizde yapılmış birçok çalışma bulunmaktadır. Bu araştırmalar, anadili olarak Türkçe öğretiminde strateji eğitimi (Doğan, 2002; Gelen, 2003; Kuzu, 2003; Karatay, 2007; Temizkan, 2007; Epçaçan, 2008; Yılmaz, 2008; Topuzkanamış, 2009; Özercan, 2010; Kaman, 2012; Gül, 2013; Emre, 2014), Türkiye'de yabancı dil öğretimi yapılan sınıflarda strateji öğretimi (Bedir, 1998; Deneme, 2008; Eraslan, 2008; Bak, 2011; Özkan Gürses, 2011) ve yabancı dil olarak Türkçe öğretiminde okutulan ders kitaplarındaki okuma becerisi ve strateji unsurları (Aygüneş, 2007; Şahin, 2010; Bayezit, 2013) hakkındadır. Elde edilen sonuçlar strateji öğretimi ile okuduğunu anlama becerisi arasında olumlu yönde bir ilişkinin olduğunu göstermektedir. Ayrıca yabancılara Türkçe öğretimi amacıyla hazırlanan kitapların okuma etkinliklerinde strateji kullanımını destekleyen etkinliklerin yetersiz olduğu sonucuna ulaşılmıştır. Bu araştırmalar içinde Türkçenin yabancı dil olarak öğretiminde okuma stratejisi öğretimini amaçlayan bir araştırmaya rastlanmamıştır. Sonuçlar doğrultusunda bu araştırmanın genel amacı okuma stratejileri öğretiminin Türkçeyi yabancı dil olarak öğrenen öğrencilerin okuduğunu anlama becerilerine etki düzeyini tespit etmek olarak belirlenmiştir.

\section{Yöntem}

Okuma stratejileri öğretiminin Türkçeyi yabancı dil olarak öğrenen öğrencilerin okuduğunu anlama becerilerine etki düzeyini belirlemeyi amaçlayan bu çalışma yarı deneysel bir araştırmadır. Bir değişkenin etkilerini gözleme ve neden-sonuç ilişkilerini test etmede kullanılan en geçerli ve güvenilir araştırma yöntemi deneysel araştırmadır (Büyüköztürk vd. 2013).

Türkçeyi yabancı dil olarak öğrenen C1 düzeyindeki öğrenciler üzerinde yapılan bu çalışmada, ön test-son teste dayalı "deney ve kontrol gruplu yarı deneysel çalışma” modeli kullanılmıştır. Deney grubu, değerlendirilecek eğitim programının uygulandığı; kontrol grubu tüm özellikler açısından deney grubuna benzeyen ancak deneysel işlemin uygulanmadığı, karşılaştırma olanağı sağlayan grup (Karasar, 2003) olarak seçilmiştir.

\section{Araştırma Grubu}

Bu çalışmanın araştırma grubunu İstanbul Üniversitesi Dil Merkezi Tophane Şubesinde C1 seviyesindeki iki sınıfta eğitim gören 20 öğrenci oluşturmaktadır. Çalışma grubunun 18'i erkek 2'si kız öğrencidir. Örneklem olarak seçilen kitlenin niteliği ve her dönemde istenen sayıda öğrenci bulunamaması sebebiyle ulaşılabilen 20 öğrenci çalışma sürecine gönüllü olarak dâhil edilmiştir. Öğrencilerin tamamı B2 seviyesinden C1 seviyesine geçebildiği için ayrıca küme analizi yapılmamış, Türkçe dil yeterlikleri açısından aynı seviyede kabul edilmiştir. Öğrenciler deney ve kontrol grubu 
olmak üzere onar kişilik iki gruba ayrılmıştır. Öğrencilerin bir önceki kur olan ve C1 kuruna geçmelerini sağlayan B2 kur sonu sınav puanları Tablo 1'de gösterilmiştir:

Tablo 1. Deney ve Kontrol Grubu B2 Kur Sınavı Okuma ve Toplam Puanları

\begin{tabular}{lcc}
\hline Öğrenci Numarası & Okuma Puanı (25 üzerinden) & B2 Kur Sınav Toplamı \\
\hline $\mathbf{1 .}$ & 23 & 89 \\
$\mathbf{2 .}$ & 13 & 66 \\
$\mathbf{3 .}$ & 19 & 82 \\
$\mathbf{4 .}$ & 18 & 69 \\
$\mathbf{5 .}$ & 17 & 78 \\
$\mathbf{6 .}$ & 14 & 69 \\
$\mathbf{7 .}$ & 11 & 65 \\
$\mathbf{8 .}$ & 17 & 83 \\
$\mathbf{9}$ & 16 & 70 \\
$\mathbf{1 0}$ & 16 & 79 \\
$\mathbf{1 1 .}$ & 10 & 63 \\
$\mathbf{1 2 .}$ & 13 & 65 \\
$\mathbf{1 3 .}$ & 9 & 60.5 \\
$\mathbf{1 4}$ & 18 & 73.5 \\
$\mathbf{1 5 .}$ & 1 & 79.5 \\
$\mathbf{1 6 .}$ & 21 & 84 \\
$\mathbf{1 7 .}$ & 21 & 92.5 \\
$\mathbf{1 8 .}$ & 24 & 67.5 \\
$\mathbf{1 9 .}$ & 18 & 78 \\
$\mathbf{2 0}$ & 19 & 71 \\
\hline
\end{tabular}

\section{Veri Toplama Araçları}

Araştırmanın verilerinin toplanmasında ön test ve son test olarak kullanılan çoktan seçmeli "B2-C1 Okuduğunu Anlama Başarı Testi” kullanılmıştır.

Ön test ve son test olarak uygulanan "B2-C1 Okuduğunu Anlama Başarı Testi (OABT)" Gaziantep Üniversitesi TÖMER ve Eskişehir Osmangazi Üniversitesi TÖMER'den alınan B2 ve C1 kur sınavlarının çoktan seçmeli soruları ile oluşturulmuştur. Soruların hazırlanması ve seçilmesinde Avrupa Dil Portfolyosu'nun belirlediği B2 ve C1 okuma becerileri ölçüt olarak alınmıştır.

İşlem

Araştırma İstanbul Üniversitesi Dil Merkezi Tophane Şubesi'nde, 2014-2015 eğitim ve öğretim yılının yaz döneminde 5 hafta süreyle 120 saatlik C1 kuru içerisinde yürütülmüşsür. Tesadüfi olarak seçilen ilk sınıf deney grubu, diğer sınıf ise kontrol grubu olarak belirlenmiştir. Uygulama süreci başlangıcında her iki gruba B2-C1 Okuduğunu Anlama ön testi uygulanmıştır.

Uygulama sürecinde deney grubunda ders kitaplarından seçilmiş metinlerle ilgili okuma stratejilerine uygun ders planları ve etkinikler geliştirilmiştir. Kontrol grubunda ise İstanbul Üniversitesi Dil Merkezinde uygulama esnasında kullanılan “istanbul Üniversitesi Dil Merkezi İstanbul Seti C1 Kitabı"ndaki etkinlikler uygulanmıştır. Strateji öğretimini örnekleyecek etkinliklerin 
Okuma Stratejileri Öğretiminin Türkçeyi Yabancı Dil Olarak Öğrenen Öğrencilerde Okuduğunu Anlama Becerisine Etkisi

hazırlanması için kullanılacak metinlerin seçiminde Türkçe eğitimi ve yabancılara Türkçe öğretimi alanında tecrübeye sahip 6 uzmanın görüşüne başvurulmuştur. Uzmanların verdikleri puanların aritmetik ortalamalarına göre "Aşkın Kimyası", "Elmas Gerdanlık", "Fatih Sultan Mehmet Mahkemede" ve "Satranç ve Tavla" metinleri uygulama sürecinde kullanılmıştır. Metinlerden ikisi öyküleyici diğer ikisi de bilgilendirici türdedir. Deney grubunda verilen eğitimde okuma öncesi stratejilerden "önbilgilere ulaşma" ve "konu hakkında ne bilindiğinin ifade edilmesi"; okuma esnasında kullanılan stratejilerden "yeni kelimeleri kontrol etme, not alma", "okuma ile birlikte anlamayı kontrol etme"; okuma sonrası kullanılan stratejilerden "metinden çıkarılan anlamı ifade etme", "bilgileri gözden geçirme" ve "özetleme" stratejilerinin öğretimi hedeflenmiştir.

Uygulama esnasında örnek okuma ve sessiz okuma yöntemleriyle öğrencilere hazırlanan materyaller üzerinde çalışacak yeterli süre verilmiştir. Strateji öğretimi amacıyla hazırlanan etkinlikler hakkında ders öğretim elemanına uygulama öncesinde bilgi verilmiş, çalışma yapraklarında yer alan etkinlikler ve sorular araştırmacıların ve öğretim elemanının rehberliğinde sınıf içinde uygulanmıştır. Araştırmacılar ve ders öğretim elemanı öğrencilerin çalışma yapraklarını kontrol etmiş, gerektiğinde anında dönüt vererek düzeltme yapmışlardır. Eğitim C1 kur sınavından iki gün önce tamamlanmıştır.

\section{Verilerin Analizi}

Deney ve kontrol grubundaki öğrencilerin $\mathrm{OABT}$ 'den aldıkları puanların ortalama ve standart sapma değerleri betimsel istatistik, ön test sonuçları arasındaki farkın olup olmadığı bağımsız t-testi, uygulanan strateji öğretiminin etkisi Ortak Değişkenli Varyans Analiz (ANCOVA) kullanılarak analiz edilmiştir.

\section{Bulgular ve Yorumlar}

Çalışma başlangııında öncelikle deney ve kontrol gruplarındaki öğrencilerin okuduğunu anlama düzeyi açısından denk olduklarının belirlenmesi amaçlanmış ve elde edilen sonuçlar bağımsız gruplarda t-testi ile kontrol edilmiş, sonuçlar Tablo 2'de sunulmuştur:

Tablo 2. Deney ve Kontrol Gruplarının ön-Test Sonuçlarına Ait Bağımsız T-Testi Sonuçları

\begin{tabular}{lcccccc}
\hline Grup & $\mathbf{n}$ & $\bar{X}$ & $\mathbf{S}$ & sd & t & $\mathbf{p}$ \\
\hline Kontrol & 10 & 27,75 & 14,92 & 18 & 1,09 &, 290 \\
Deney & 10 & 35,00 & 14,81 & & & \\
\hline
\end{tabular}

Bağımsız gruplarda t-testi sonuçlarına göre deney ve kontrol gruplarındaki öğrencilerin öntest puanlarının ortalamaları arasında $\left[\mathrm{t}_{(18)}=1.090, \mathrm{p}>0,05\right]$ istatistiksel olarak anlamlı bir fark olmadığı belirlenmiştir. Bu bulgu başlangıçta iki grubun başarı düzeylerinin istatistiksel olarak birbirine yakın 
olduğunu göstermektedir. Uygulama süreci öncesi grupların benzer başarı düzeylerinde bulunması çalışmanın eşit şartlara sahip gruplar üzerinde yürütüldüğünün en önemli göstergesidir.

Deney ve kontrol gruplarında bulunan öğrencilere uygulama süreci sonunda uygulanan OABT'ye ilişkin son test sonuçları Tablo 3'te sunulmuştur:

Tablo 3. Deney ve Kontrol Grupları için Başarı Puanı Sonuçları

\begin{tabular}{lccc}
\hline & ORTALAMA & STANDART SAPMA & N \\
\hline Kontrol Grubu & 30,00 & 12,85 & 10 \\
Deney Grubu & 53,75 & 11,38 & 10
\end{tabular}

Tablo 3'te görüldüğg̈ gibi uygulanan son-testte kontrol grubu öğrencilerinin aritmetik puan ortalaması 30,00 iken deney grubunun puanlarının aritmetik ortalamasının 53,75 olduğu görülmektedir. Bu bulguya göre deney grubu ile kontrol grubunun son-test puanlarının aritmetik ortalamaları arasında deney grubunun lehine $23,75^{\prime}$ lik bir fark olduğu görülmektedir.

Deneysel bir çalışmada bağımlı bir değişken birçok farklı değişkenden etkilenebilir. Bu türdeki değişkenlerin etkisi gruplar arasında farklılık gösterebilir. Bu farklılı̆ın olup olmadığını ortaya çıkarmak amacıyla ortak değişkenli varyans analizi (ANCOVA) yapılır. Deneysel desenin uygulanmasında kontrol altına alınamayan çevresel faktörler, doğrusal bir regresyon metodu ile devre dışı bırakılabilir. ANCOVA, varyans analizi ve regresyon analizini eşzamanlı kullanarak deneysel işlemdeki gerçek etkinin ortaya çıkmasını sağlar (Büyüköztürk, 2003). Ancak testin uygulanabilmesi için ölçümlerin homojen dağılım göstermesi gerekmektedir. Bu sebeple öncelikle Levene Testi ile ölçümlerin homojenliği incelenmiş ve sonuçlar Tablo 4'te verilmiştir:

Tablo 4. Levene's Homojenlik Testi Sonuçları

\begin{tabular}{ccccc}
\hline & $\mathbf{F}$ & $\mathbf{d f 1}$ & $\mathbf{d f 2}$ & $\mathbf{p}$ \\
\hline Son-OABT & 4,075 & 1 & 18 &, 059 \\
\hline
\end{tabular}

$n=20, p>0,05$

Tablo 4'teki p değerlerinin istatistiksel olarak anlamlı olmaması ölçümlerin her iki grupta da homojen olduğunun bir göstergesidir. Ortak değişkenli varyans analizinin varsayımlarının kontrol edilmesinden sonra araştırmanın genel amacını test edebilmek amacıyla ANCOVA analizi yapılmış ve tüm hipotez 0,05 güven düzeyinde test edilmiştir.

Tablo 5. Ortak Değişkenli Varyans Analiz (ANCOVA) Sonuçları

\begin{tabular}{llccccc}
\hline Kaynak & $\begin{array}{l}\text { Bağımlı } \\
\text { Değişkenler }\end{array}$ & df & $\begin{array}{c}\text { Ortalamalar } \\
\text { Karesi }\end{array}$ & F & p & $\begin{array}{c}\text { Kısmi Eta } \\
\text { Karesi }\end{array}$ \\
\hline Ön-OABT & Son-OABT & 1 & 496,79 & 3,91 &, 064 &, 187 \\
Grup & Son-OABT & 1 & 2105,78 & 16,60 &, 001 &, 494 \\
\hline
\end{tabular}

$n=20, \quad{ }^{*}<0,05$ 
Okuma Stratejileri Öğretiminin Türkçeyi Yabancı Dil Olarak Öğrenen Öğrencilerde Okuduğunu Anlama Becerisine Etkisi

Tablo 5'te görüldüğü gibi ortalama puanlar arasında anlamlı bir fark bulunmuştur $\left(\mathrm{F}_{(1)}=\right.$ $\left.16,60, p<0,05, \eta^{2}=0,494\right)$. Bu sonuç araştırma sürecinde deney grubuna öğretilen okuduğunu anlama stratejilerinin deney grubu öğrencilerinin son-OABT puan ortalamaları ile kontrol grubundaki öğrencilern son-OABT puanları ortalamaları arasında strateji öğretimi yapılan sınıf lehine anlamlı bir fark olduğunu göstermektedir. Çoklu eta kare değerinin 0,494 olması bağımlı değişkendeki değişimin \% 49,4'ünün strateji öğretiminden kaynaklandığını göstermektedir.

\section{Sonuç}

Okuma stratejilerinin Türkçeyi yabancı dil olarak öğrenen öğrencilerin okuduğunu anlama becerilerine etkisini belirlemeyi amaçlayan bu araştırmadan elde edilen bulgular $\left(F_{(1)}=16,60, p<0,05\right.$, $\left.\eta^{2}=0,494\right)$ strateji öğretiminin okuduğunu anlama başarısına geniş düzeyde katkısı olduğunu göstermektedir. Elde edilen sonuçlar okuma eğitiminde strateji kullanımı üzerine daha önce yapılan çalışmalarla benzerlikler göstermektedir. Anadili öğretiminde strateji eğitimi konusunda yapılan araştırmalar strateji öğretiminin öğrencilerde okuduğunu anlama becerileri, motivasyon, Türkçe dersine ilişkin tutum, öz yeterlik algısı, hafızada tutma, bilişsel farkındalık becerileri, diğer öğrenme alanları, kitap okuma alışkanlığı ve akademik başarı boyutlarını olumlu yönde etkilediğini (Doğan, 2002; Gelen, 2003; Kuzu, 2003; Karatay, 2007; Temizkan, 2007; Epçaçan, 2008; Yılmaz, 2008; Topuzkanmış, 2009; Gül, 2013; Emre, 2014) göstermektedir. Bu sonuçlar, çalışmanın sonuçlarını destekler niteliktedir.

Türkiye'de yabancı dil eğitimi yapılan sınıflardaki strateji eğitimiyle ilgili yapılan çalışmalarda bu araştırma sonuçlarına benzer şekilde özetleme, yeni kelimeleri kontrol etme, not alma ve sözcük anlamını kestirme stratejilerinin okduğunu anlama becerilerini olumlu yönde etkilediği, bilişsel öğrenme stratejileri ile okuma anlama arasında güçlü bir ilişki olduğu sonucuna ulaşılmıştır (Bedir, 1998; Deneme, 2008; Eraslan, 2008). Strateji öğretimiyle ilgili yurt dışında yapılan araştırma sonuçları da (Block, 1986; Upton, 1997; Padron ve Waxman, 1988; Jimenez, Garcia ve Pearson, 1996; Carell, 1985; Hamp-Lyons, 1985; Kern, 1989) zayıf okuyuculara oranla strateji eğitimini alan bireylerin anlamlandırma süreçlerini daha iyi takip edebildiğini, stratejilerin birinci ve ikinci dilde okumayı destekleyici nitelikte olduğunu, "yazılı özetleme", "her şeyin hatırlanıp hatırlanmadığını görmek için önemli yerlerin altını çizme" ve "not alma" stratejilerinin okuduğunu anlamayı olumlu etkilediğini göstermektedir.

$\mathrm{Bu}$ araştırmanın sonuçları ile ana dili ve yabancı dil eğitiminde yapılan çalışmalar incelendiğinde okumada strateji eğitiminin okuduğunu anlama becerilerini olumlu yönde etkilediği görülmektedir. Türkçeyi yabancı dil olarak öğrenen öğrencilerin okuma becerilerinin geliştirilmesi 
sürecinde strateji eğitimine daha planlı bir şekilde yer verilmesi hem okuma hem de anlama sürecini kolaylaştıracaktır.

\section{Kaynaklar}

Akyol, H. (2013). Okuma. A. Kırkkılıç ve H. Akyol (Ed.) Ilköğretimde Türkçe öğretimi (ss. 15-48). Ankara: Pegem Akademi Yayıncılık.

Aygüneş, M. (2007). Yabancı dil olarak Türkçe öğretiminde okuma becerisini geliştirme yolları. İzmir: Dokuz Eylül Üniversitesi, Yayımlanmamış Yüksek Lisans Tezi

Bak, Ç. (2011). Üniversite öğrencilerinin okuma stratejilerini kullanımına dair diller arası bir karşılaştırma: birinci dil olarak türkçe, ikinci dil olarak fransızca ve üçüncü dil olarak ingilizce. İstanbul: Marmara Üniversitesi, Yayınlanmamış Yüksek Lisans Tezi.

Barnett, M. A. (1988). Reading Through Context: How Real and Perceived Strategy Use Affects L2 Comprehension. The Modem Language Journal, 72, 150-162.

Bauman, J. F. (1984). The Effectiveness Of A Direct Instruction Paradigm For Teaching Main Idea Comprehension. Reading Research Quarterly, 20, 93-117.

Bayezit, H. (2013). Yabancı dil olarak türkçe ve ingilizce ders kitaplarındaki öğrenme stratejilerinin kullanımı. İzmir: Dokuz Eylül Üniversitesi, Yayınlanmamış Yüksek Lisans Tezi.

Beaugrande, R. A. de\& Dressler, W. U. (1981). Introduction to text linguistics. New York: Longman Inc.

Bedir, H. (1998). Türk öğrencilerin okuma anlama yetilerinde bilişsel öğrenme stratejileri kullanmalarının etkisi. Adana: Çukurova Üniversitesi, Yayınlanmamış Doktora Tezi.

Block, E. (1986). The Comprehension Strategies of Second Language Readers. TESOL Quarterly, 20/3, 463-494.

Büyüköztürk, Ş. (2003). Sosyal blimler için veri analizi el kitabı. (3. Baskı). Ankara: PegemA Yayıncılık.

Büyüköztürk, Ş., Kılıç Çakmak, E., Akgün, Ö. E., Karadeniz, Ş. \& Demirel, F. (2013). Bilimsel araştırma yöntemleri. Ankara: Pegem Akademi Yayınları.

Carrell, P. L. (1985). Facilitating ESL Reading by Text Structure. TESOL Quarterly, 19, 727-752.

Council of Europe (2002). Common european framework of reference for languages. Cambridge: CUP. https://europass.cedefop.europa.eu/tr/resources/european-language-levels-cefr, $\quad$ Erişim Tarihi 15.01.2016

Deneme, S. (2008). Yabancı dilde yazma becerisinin gelişiminde özetleme tekniğinin öğretimi ve başarıya etkisi. Ankara: Ankara Üniversitesi, Yayınlanmamış Doktora Tezi.

Doğan, B. (2002). Strateji öğretiminin işbirlikçi ve geleneksel sınıflarda okuduğunu anlama becerileri, güdü ve hatırda tutma üzerindeki etkileri. İzmir: Dokuz Eylül Üniversitesi, Yayınlanmamış Doktora Tezi.

Emre, Y. (2014). Farklı akademik seviyedeki 4. sınıf öğrencilerinin okuma stratejilerini kullanma durumları. Kütahya: Dumlupınar Üniversitesi, Yayınlanmamış Yüksek Lisans Tezi.

Epçaçan, C. (2008). Okuduğunu anlama stratejilerinin bilişsel ve duyuşsal öğrenme ürünlerine etkisi. Ankara: Hacettepe Üniversitesi, Yayınlanmamış Doktora Tezi.

Eraslan, E. (2008). Yabancı dil öğretiminde sözcügüün anlamını kestirme starejisinin okuduğunu anlamaya etkisi. Ankara: Hacettepe Üniversitesi, Yayınlanmamış Yüksek Lisans Tezi.

Ertürk, S. (1972). Eğitimde program geliştirme. Ankara: Yelkentepe Yayınları.

Gelen, i. (2003). Bilişsel farkındalık stratejilerinin Türkçe dersine ilişkin tutum, okuduğunu anlama ve kalıcılığa etkisi. Adana: Çukurova Üniversitesi, Yayınlanmamış Doktora Tezi. 


\section{Okuma Stratejileri Öğretiminin Türkçeyi Yabancı Dil Olarak Öğrenen Öğrencilerde Okuduğunu Anlama Becerisine Etkisi}

Gül, M. (2013). Ortaokul 6-7-8 sınıf öğrencilerinin kitap okuma amaç ve stratejileri. Kayseri: Erciyes Üniversitesi, Yayınlanmamış Yüksek Lisans Tezi.

Güneş, F. (2013). Türkçe öğretimi yaklaşımlar ve modeller. Ankara: Pegem Akademi Yayınları.

Halliday, M. A. K. ve Hasan, R. (1976). Cohesion in English. New York: Longman Group UK Limited.

Hamp-Lyons, L. (1985). Two Approaches To Reading: A Classroom-Based Study. Reading in a Foreign Language, 3, 363-373.

Hosenfeld, C. (1977). A preliminary investigation of the reading strategies of successful and nonsuccessful second language readers. System, 5, 110-123.

İşeri, K. (1998). Okuma Ediniminin Eğitimsel İşlevi. Tömer Dil Dergisi, 70, 5-18.

Janzen, J. (2003). Developing Strategic Readers in Elementary School. Reading Psychology: an International Quarterly, 24, 25-55.

Kaman, Ş. (2012). Akıcı okuma stratesilerini kullanmanın ilköğretim üçüncü sınıf öğrencilerinde okuma becerisini geliştirmeye etkisi. Kırşehir: Ahi Evran Üniversitesi, Yayınlanmamış Yüksek Lisans Tezi.

Karasar, N. (2003). Bilimsel araştırma yöntemi. (12. Baskı). Ankara: Nobel Yayın Dağıtım.

Karatay, H. (2007). Ilköğretim Türkçe öğretmeni adaylarının okuduğunu anlama becerileri üzerine alan araştırması. Ankara: Gazi Üniversitesi, Yayınlanmamış Doktora Tezi.

Kern, R. G. (1989). Second Language Reading Strategy Instruction: Its Effects on Comprehension and Word Inference Ability. The Modern Language Journal, 73, 135-149.

Knight, S., Padron, Y. \& Waxman, H. C. (1985). The Cognitive Reading Strategies of ESL Students. TESOL Quarterly, 19, 789-792.

Koç, N. (1998). Yabancılar için dil bilgisi öğrenci kitabı (2. Baskı). İstanbul: İnkılap Kitabevi.

Kuzu, T. (2003). Etkileşimsel modele uygun okuma öğretiminin Türkçe bilgilendirici metinleri anlama düzeyine etkisi. Ankara: Ankara Üniversitesi, Yayınlanmamış Doktora Tezi.

Lovett, S. B. ve Flavell, J. H. (1990). Understanding and Remembering: Childrens Knowledge About The Differential Effects of Strategy and Task Variables on Comprehension And Memorization. Child Development, 61/6, 1842-1858.

MEB (2015). Türkçe dersi (1-8. sınıflar) öğretim programı. Ankara: Millî Eğitim Bakanlığı Yayınları.

Özercan, M. G. (2010). ilköğretim altıncı sınıf öğrencilerinin kullandığı öğrenme ve okuma stratejilerinin seviye belirleme sınav sonuçlarıyla karşılaştırıması. Elazığ: Fırat Üniversitesi, Yayınlanmamış Yüksek Lisans Tezi.

Özkan Gürses, M. (2011). Fransızca yabancı dil dersinde bilişsel akademik dil öğrenme yaklaşımına dayalı okuma stratejileri öğretiminin okuduğunu anlamaya ve strateji kullanmaya etkisi Eskişehir Osmangazi Üniversitesi örneği. Eskişehir: Eskişehir Osmangazi Üniversitesi, Yayınlanmamış Doktora Tezi.

Paris, S. G., Wasik B. A. \& Turner J. C. (1996). The development of strategic readers'. R. Barr, M. Kamil, P. Mosenthal \& P. D. Pearson in (Eds.). Handbook of reading research (pp. 609-640). New York: Longman.

Sarig, G. (1987). High-level reading in the first and in the foreign language: some comparative process data. J. Devine, P. L. Carrell, \& D. E. Eskey (Eds.). Research in reading in English as a second language (pp. 105123). Washington, DC: Teachers of English to Speakers of Other Languages.

Schunk, D. H. (2009). Öğrenme teorileri. (Çev. Ed.: M. Şahin). Ankara: Nobel Yayınevi.

Sever, S. (1997). Türkçe öğretimi ve tam öğrenme. Ankara: Anı Yayıncılık.

Smith, E. E. \& Kosslyn, S. M. (2014). Bilişsel psikoloji. (Çev. Ed.: M. Şahin). Ankara: Nobel Yayınevi. 
Şahin, A. (2010). Avrupa dil gelişim dosyası bağlamında yabancı dil olarak Türkçe öğretiminde okuma becerisini geliştirmeye yönelik malzeme oluşturma. İzmir: Dokuz Eylül Üniversitesi, Yayınlanmamış Yüksek Lisans Tezi.

TDK (Türk Dil Kurumu) (2005). Türkçe sözlük. Ankara: Türk Dil Kurumu Yayınları.

Temizkan, M. (2007). Ilköğretim ikinci kademe Türkçe derslerinde okuma stratejilerinin okuduğunu anlama üzerindeki etkisi. Ankara: Gazi Üniversitesi, Yayınlanmamış Doktora Tezi.

Topuzkanamış, E. (2009). Öğretmen adaylarının okuduğunu anlama ve okuma stratejilerini kullanma düzeyleri. Balıkesir: Balıkesir Üniversitesi, Yayınlanmamış Yüksek Lisans Tezi.

Upton, T. A. (1997). First and Second Language Use in Reading Comprehension Strategies of Japanese ESL Students. The Electronic Journal for English as a Second Language, 3(1), 1-24.

Wellman, H. M. (1988). The early development of memory strategies. F.E. Weinhert \& M. Perlmutter (Eds.). Memory development: Universal changes and individual differences (pp. 3-29). Hillsdale, N.J.: Lawrence Erlbaum Associates.

Yılmaz, S. (2008). Başarılı ve başarısız 7.sınıf öğrencilerinin Türkçe derslerinde kullandıkları okuma stratejileri ve yaratıcılık düzeyleri. İzmir: Dokuz Eylül Üniversitesi, Yayınlanmamış Yüksek Lisans Tezi. 